\title{
The Cost of Panai As the Marriage Requirement for the Migrant Bugis Tribe under Adat Law
}

\author{
Dhelima Putri Laksana* \\ University of Jember, Indonesia
}

\section{Dominikus Rato}

University of Jember, Indonesia

\author{
Emi Zulaikha \\ University of Jember, Indonesia
}

\begin{abstract}
This research aims to examine the legal phenomena of the application of the panai money, the cost imposed for the migrant Bugis customary law community in Sukabumi Village, Mayangan District, Probolinggo City, East Java. In other words, Panai' money is such customary money which must be handed over in Bugis tribal marriages. The data analysis method used is descriptive qualitative. Data collection techniques using literature study, observation, interviews, and documentation. The results of this study indicate that the submission of panai money has become a tradition that originated from an ancestor that is still valid today. Due to the high panai money, however, many of the Bugis people who wander no longer use panai money, as it takes into account the weakness of their customary values, as well as the many other cultures that influence, but there are still people who still defend it because of their strong customary values which they still hold even though in the migrant area. Because panai money 'is a tradition that has long been a benchmark for Bugis people, this tradition still strongly considers moral sanctions, and the avoidance of this money is responded by some people to decide to elope.
\end{abstract}

KEYWORDS: Migrant Bugis Tribe, Marriage Law, Adat Law.

Submitted: 12/02/2020 Reviewed: 14/02/2020 Accepted: 10/03/2020

Copyright $(2020$ by Author(s)

This work is licensed under a Creative Commons Attribution-ShareAlike 4.0 International License. All writings published in this journal are personal views of the authors and do not represent the views of this journal and the author's affiliated institutions.

* Corresponding authors' e-mail: pdhelima@gmail.com 


\section{INTRODUCTION}

Marriage is a lifelong bond, which has been authorized by God. Marriage is also a medium for someone's life, where it brings a man and a woman together to form a new life. Marriage is a gate of the formation of a family that is in the life of the community, which is sometimes guaranteed the survival of the community in marriage. ${ }^{1}$ Marriage not only requires something to just know, care, fulfillment, and commitment, but also requires an awareness of God in human life that leads him to the right path, the path to true happiness, and eternal. With marriage, it is what distinguishes humans from other God's creatures is the stage of unification to produce offspring, because humans in addition to having lust also have a mind which can think which is best for their lives in the future. This is stated in the 1945 Constitution Article 28B paragraph (1) that everyone has the right to form a family and continue the family and continue the descent through a legal marriage.

The purpose of the verse is that the marriage is legally declared if those who do marriages according to Islam, then the recording can be done at the Office of Religious Affairs (KUA), while for those who are Catholic, Christian, Buddhist, Hindu, the recording can be done at the Civil Registry Office (CAPIL). If the marriage has been registered, then all family members are guaranteed life by the state. In Article 1 of the Marriage Law Number 1 of 1974 concerning Marriage states that marriage is an inner-outer bond between a man and a woman as husband and wife with the aim of forming a happy, eternal family (household) based on a Godhead.

The importance of marriage is also felt by the people in South Sulawesi Province, specifically Makassar. For them marriage is very important to continue their offspring. The long marriage process, as well as the many mandatory requirements that must be met, make the Bugis people have to bear the shame if one of the conditions is not met. In accordance with the

1 Rato, Dominikus 2011. Marriage Law and Customary Inheritance (Kinship System, Form of Marriage and Customary Inheritance Patterns in Indonesia). Surabaya: Laksbang Yustitia. at 14. 
customs prevailing in Bugis-Makassar, most of the requirements in conducting marriages are borne by the men, and almost all costs in carrying out the Bugis traditional marriages are borne by the men. ${ }^{2}$.

One of the conditions in a marriage in the Bugis tribe in Makassar, South Sulawesi is to provide panai money, or what is often called the Bugis tribe community, do 'menre'/doi 'panai (doi 'shopping) 3 . Panai own money means the amount of money that will be fulfilled or given by men to women before stepping into the marriage procession given at the time of mapa'nessa which in the event negotiates and decides on everything related with a marriage procession. ${ }^{4}$

The panai money itself began in the Dutch colonial era. At that time the Dutch youth arbitrarily married the Bugis-Makassar woman he wanted, but after getting them he remarried to marry another woman, and left his wife. Until finally the culture left an impression on the Bugis-Makassar community. This is what makes Bugis women of ancient times seemingly insignificant and have no self-respect. However, gradually the culture has changed, since the arrival of a young man to marry a daughter of a Bugis aristocratic family. Parties from the daughter's family refused not without reason, but seeing that they had heard the culture that had once happened, they worried that her daughter's fate would be the same as other women. Finally, to prove whether the young man was serious or not, the parents of the daughter requested that the young man provide the money that is now known as the 'predetermined' money. This was done not to burden the young man, but to raise the degree of women at that time. After the dowry is determined, the young man goes to find a way to get the dowry. Arrange the young man, to find money for the girl he wants to marry. After years of wandering, finally the money desired by the daughter's parents was fulfilled.

2 Lamallongeng. 2007. The Dynamics of Indigenous Marriage in the Bugis Bone Society. Bone: Culture \& Tourism Office of BoneRegency at 6.

3 Sri Rahayu Yudi. 2015. "Nai's Money: Between Love and Prestige". Journal of Jamal Multiparadigm Accounting. Volume. 6 Number 2 at 225.

4 Yunus, 2018. Islamic Values in the Marriage Process of the Bugis Society. Journal of Humanities: Islam and Culture. Volume 2, No. 1, June 2018 at 90. 
The young man went to meet the daughter's parents and give money in accordance with what they want. Seeing the sincerity of the young man, the daughter's parents gave up their children to become his wife.

The amount of panai money itself is influenced by many factors, one of which is the social status inherent in the two brides' candidates both from the social status of men and the social status of women. The higher the status the higher the panai money will be given. It is not uncommon for marriages to be canceled because of the high 'panai money', the party of men must give up the marriage that was dreamed of since they were unable to meet the demand for the 'panai money'. With the reality that is happening, the meaning of panai money 'itself has changed from the real intention, panai money' is used as a place of prestige to show excessive economic capacity, because of the high cash money 'which is the main requirement in Bugis marriage, if the conditions are not filled with men has been regarded as shame or "ma siri "' (shame or self-esteem humiliated)..$^{5}$ In fact, it is not uncommon for requests from panai money to be used as weapons for the refusal of women to the men who come to propose if the men are not sanctioned by the parents of the women, the women will ask for the panai money 'as high as possible with the intention that the men were unable to meet the demand for the panai money.

Many Bugis people migrate, making panai money 'no longer used in the marriage process. The Bugis people who now migrate to Java, especially the Probolinggo Regency, also no longer use the panai money 'as their main requirement and this makes it easier to dig up information because of the large number of Bugis people who have settled in Probolinggo. In addition, because the panai money 'is one of the characteristics of marriages in the tribe Bugis, as well as the amount of panai money' which is also influenced by various factors, making the panai attractive to be studied.

5 Agustar, 2018, "The Tradition of Panaik Money in the Marriage of the Bugis Tribe in the Community of Sanglar Village, Reteh District, Indragiri Hilir Regency". JOM FISIP. Volume. 5 Number. 1. at 3. 
Based on the description above, this article is organized into three parts. The first part will review the meaning of panai. The second part analyzes the Bugis tribe community overseas who still retain the tradition of panai. The third part analyzes the impact of the money tradition panai if it is not provided. At the end of the writing the conclusions will contain the tradition of panai which is still being carried out by the Bugis tribe overseas and its impact if not given.

\section{PANAI MONEY: AN OVERVIEW}

Customary law is the law governing the forms of customary marriage, how to apply according to the customs of each region, customary marriage ceremonies, and termination of customary marriage in Indonesia. ${ }^{6}$ In marriage there are also a number of things that make a marriage valid. The legality of marriage according to the customary law community in Indonesia, for adherents of religion in general depends on the religion adopted by the community concerned. That is, if a marriage has been carried out according to the rules of religious law, then the marriage will be valid according to customary law. ${ }^{7}$

In the view of the Bugis indigenous community, marriage itself aims to build, foster, and maintain harmonious family relations and kinship, and peace. That is because the values that live in indigenous peoples concern the purpose of marriage which must be regulated in an orderly manner, so as to avoid embarrassing irregularities and violations that can bring down the dignity, family honor and related relatives.

In South Sulawesi, especially the Bugis-Makassar tribe, marriage is considered sacred by the community, because for them marriage is a bond between the family of the male and the family of the female which will form

6 Rosdalina., 2016. Bugis Community Marriage Implementation of Law Number 1 of 1974 concerning Marriage. Yogyakarta: Istana Publishing at 97.

7 Hilman, Hadikusuma. 2007. Indonesian Marriage Law. According to the Law, Customary Law, Customary Law. Bandung: Mandar Maju at 26. 
a larger family unit. That thinking makes them appreciate marriage so much. One of them appreciates the existence of a tradition in the marriage of the Bugis-Makassar tribe that is closely related to family ties, namely the culture of siri (shame) regarding panai 'money or nai pacce. ${ }^{8}$ The recognition of the Bugis tribe community also confirms that in fact panai money 'is a characteristic of the local Bugis marriage customs. ${ }^{9}$ They also justified that panai money 'is a culture that must exist and is obligatory to do when making a marriage.

Panai money itself is traditional money given by men to women in accordance with the agreement of the families of both parties. The purpose of the 'panai money' is to be used as a marriage fee when the marriage takes place at the bride's house. ${ }^{10}$ The function of the panai money tradition itself is the gift given economically which brings a shift in wealth because the panai money given has a high value. ${ }^{11}$ Socially, Bugis women have a high position and are respected. So overall the panai money 'is a gift given by the prospective bridegroom to the prospective bride. But the panai 'money will later be given to the parents of the women to be used as a wedding party. Marriage parties can actually be done in two places first at the women's residence, then at the men's residence. For parties which are held at women's places, the money used is usually 'panai money to buy the party preparations, while the parties that are held at the place of men use their own costs from the men. ${ }^{12}$ For the Bugis community a wedding party is an obligatory event to be held at the time of the wedding, even though the party is held in a simple form. This was done because according to the Bugis community, the wedding was held as a form of gratitude to the creator, where they could

8 Hajra Yansa, et, al., 2016, Panai Money and Women's Social Status in the Siri 'Cultural Perspective of the Bugis Marriage of Makassar, South Sulawesi. Pena Journal. Volume 3. Number 2. at 526.

9 Interviews with Mr. H. Muhammad Tahir and Hj.Samsu Nujung husband and wife of a native Bugis tribe overseas on 3 December 2018

10 Soerojo Wignjodipoero. 1995. Introduction and Principles of Customary Law. Jakarta: Gunung Agung at 37.

11 Hajra Yansa, supra note 8 at 526.

12 Interview with Mr. Agus and Mrs. Siti Hajar, an ethnic Bugis husband and wife overseas on December 18, 2018 at the house of Mr. Agus and Mrs. Siti Hajar 
gather with families far and near to watch the bride and groom join in the aisle. $^{13}$

Determination of the panai money itself is based on several determinants which according to Lamallongen usually pay attention to objective factors and subjective factors in mate selection, namely regarding the readiness to settle down. Objective factors that focus on issues concerning the economy, self-maturity, mental, character, and intelligence of both parties. The subjective factor focuses on the basis of love from both parties, which relates to feeling and loving one another.

Panai money 'is given to the family of women during the mappa'nessa which besides talking about the amount of panai money', also determines the day and date of marriage and everything related to marriage. If the panai money given by the bride and groom is big, then the wedding celebration is held lively, but conversely if the panai money is given a little then the wedding party is also simple too. The 'panai money' tradition cannot apply if marriages are carried out by men who marry non-Buginese women. That is because the Bugis man will follow the culture of the woman's family he will marry, so the panai money applies if the marriage is carried out by the Bugis man and woman. However, this tradition is generally still maintained if Bugis women are proposed by non-Bugis men. This happens because in the Bugis traditional marriage tradition, women are the picked up party, so the customs used are the customs of the women. ${ }^{14}$

The panai money given by these men, is not counted as a marriage dowry, but rather traditional money which is compulsory with the amount agreed upon by the families of both parties. Determination of the panai money 'is done when applying is not without reason but, the determination was made to reduce the frequency of divorce. ${ }^{15}$ The panai money itself can be replaced with items such as cars, houses or land according to the agreement, but the money must still be available even if only a little, because the goods given are

13 Rosdalina, 2016, supra note 6 at 72.

14 Sri Rahayu Yudi, 2015, supra note 3 at 232.

15 Rosdalina, 2016, supra note 6 at 64. 
already of high value, so the rest of the panai money needn't be given in large quantities anyway. ${ }^{16}$ So with the determination of the amount of the panai 'money the man intended to think of suing for his wife's divorce given the huge cost he had incurred during the application. These high requirements were put forward so that men would appreciate the efforts of parents who gave birth to their daughters, raising them with affection to growing up. ${ }^{17}$ For the Bugis community, especially parents, a high amount of panai money is also likened to a substitute for milk money while they are raising their children. Panai money 'is not directly given to the bride-to-be like a bride, but rather is given to the prospective wife's parents, so it can be said that the absolute right of the panai money holder' is the prospective wife's parents to finance all the needs of the wedding party.

For the Bugis community, substantial determination of spending money based on social status, education, descent, etc. is already a tradition and habit of the Bugis community. ${ }^{18}$ The reason for the tradition must be followed other than because it has existed since ancient times, another reason is because if they do not do that tradition and they follow, it will cause a moral burden for their families, which is a form of ridicule from the surrounding community and even family. ${ }^{19}$

Of all the assumptions about the tradition of panai money' ranging from the amount of panai money, determinant of the amount, to the negative assumption of this tradition, actually panai money 'has its own meaning for the Bugis community, among others. First, social Meaning. Panai money 'is a tradition to maintain the status and self-esteem of Bugis women, bearing in mind that in the past Dutch youth who arbitrarily dropped the pride of Bugis women by remarrying with other women. Panai 'money is also done by the parents of the woman to test the seriousness of the man to marry his

16 Interview with $\mathrm{Hj}$. Rika, the wife of $\mathrm{H}$. Arifin, a native and married Bugis couple on December 30, 2018 at Hj. Rika

17 Interview with $\mathrm{H}$. Bustamin husband of a husband and wife of a native Bugis tribe overseas on 18 December 2018 at the home of H. Bustamin

18 Rosdalina, supra note 6 at 64.

19

Ibid. 
daughter. Second, economic Meaning. Panai money 'is a tradition which is used as a form of help made by the Bugis tribe community to ease the cost of marriage. Third, legal Meaning. Panai Money which is a tradition that has existed since the days of the ancients which is still used today, if it is no longer used, it will cause a canceled marriage because men cannot fulfill the conditions of Bugis marriage and must bear the shame of their actions. Fourth, cultural Meaning. Where people who still retain the panai money tradition as a tradition that must be preserved, so the community continues to do it even if they are not in Bugis or in the overseas area.

\section{PANAI IN THE BUGIS TRADITION}

Bugis-Makassar is an area that has fertile plains so that almost all Bugis people choose to work as farmers. However, because the cost of living from working as a farmer is not able to support their daily lives, finally some people, especially the Bugis youth, choose another livelihood, namely as a fisherman, Not only turned into a fisherman in his own area, the Bugis youth also went abroad to supplement his living expenses. They decided to go abroad to support their lives and family in their hometowns, but they also worked hard for very expensive marriages. Most of them work as traders in their overseas areas, because keeping in mind the tradition of panai money that has been passed down for generations. ${ }^{20}$

The hard work done by the Bugis youth is inseparable from the philosophy of marriage, which is still used as a guide before deciding to get married. Philosophy contains the things that must be owned by a young man if he wants to get married. The philosophy is "Around the Kitchen Seven Times" which in Bugis reads makkalu kitcheneng wekka pitu. This philosophy is intended for young Bugis who want to get married or want to let go of their bachelor.

20 Interview with Mr. Agus and Mrs. Siti Hajar, an ethnic Bugis husband and wife overseas on December 18, 2018 at the house of Mr. Agus and Mrs. Siti Hajar. 
The number seven in this philosophy means that there are seven stages or conditions that must be understood before fostering a family in a marriage bond or entering domestic life. The first stage includes the first who has mental readiness, the second has the maturity of thinking, the third understands responsibility, the fourth is able to be a good leader or priest for his family, the fifth is able to be wise in solving problems, the sixth is able to be a good role model for his family, Seventh is able to become someone who has a consistent nature. If all these stages have been mastered, it means that the Bugis youth are considered able to settle down.

This philosophy is a motivation for the Bugis youth to go abroad, in addition to the lover of hearts who will become his wife, meet the conditions of marriage, also used to prepare for the marriage party because in fact in the Bugis tribe the marriage is done by parents matching their children. ${ }^{21}$ In Bugis custom, marriage is not only about giving dowry and marriage contract like marriage in general, but there are still requirements that must be met before marriage. The requirement is the existence of a large sum of money sometimes not small, depending on the agreement of the two families. Determining the amount of panai money, one of which can also be seen from the strata of a man or strata of women. Achieving such a high degree in a social stratification system for the aristocracy is very important. But the recognition of the social strata is seen not only from marriage but can also occur because of other public activities, such as the place where men work.

Panai money itself is a tradition that has existed since previous ancestors to this day is still ongoing and is used by the community as the main requirement and as a characteristic of marriages from Bugis Adat. If seen from the early history of the 'panai money', the purpose and purpose of the panai money 'was symbolized as a form of appreciation to the women, but now it has turned into spending money, in preparation for a wedding.

21 Interview with $\mathrm{Hj}$. Rika, the wife of $\mathrm{H}$. Arifin, a native and married Bugis couple on December 30, 2018 at Hj. Rika. 
The panai money which has changed function has now become a place of prestige to maintain the dignity of the family, making consideration of the perception of others outside the family about the bride and groom. And because of this, many Bugis young men decided to migrate, bearing in mind that there was a large amount of panai money to hold a wedding, as well as many determinants of the panai money, from education, social equivalents, to where the men worked. guys. They will consider other people's perceptions about the amount of panai 'if they give panai money' in a low amount, given the existence of culture siri'.

Changing the aims and objectives of the 'panai money tradition' currently results in many men perceiving that panai money 'is a burdensome tradition, if the men come from lower middle income families, even feeling burdened by the tradition of panai money' which is valued This height is the main requirement for the marriage process. ${ }^{22}$

The change in the function of panai money 'caused many people to think about the high amount of panai money' which made most men migrate to look for women outside Makassar with the intention that when they were married, they did not have to pay a lot of money. The large number of people who migrate is also one factor that the panai money tradition 'is no longer used as the main requirement in marriage. Apart from the fact that their traditional values are weak, the existence of foreign cultures from each region also makes the tradition untenable. However, there are still many people who still maintain the tradition because of the strong customary values they hold so that panai money 'remains a mandatory requirement in conducting marriages, other than because of strong customary values the Bugis people consider that the panai money tradition' is a tradition from the ancestors which must be preserved, and must be guarded. For them, besides the panai money, which is used as the cost of a wedding, the money is also used as a tradition for gathering families from various regions, if the tradition is not practiced, then the families of both parties, especially women will be

22 Hajra Yansa, supra note 3 at 529. 
ashamed. ${ }^{23}$ So some of the Bugis people who wander still maintain the tradition even though the panai money given is not too high.

\section{IMPACTS OF THE PANAI TRADITION}

Panai money has long been a benchmark for the Bugis community, including in preparing for a wedding. Therefore, repeated behavior is carried out and occurs, if it is not done it will result in moral sanctions on the family, then the habit can be used as a source or guide in Bugis traditional marriages. ${ }^{24}$ So it can't be if a habit that has long been lived suddenly has to stop being done or deliberately not doing it for a reason. Usually a reason for the tradition of 'panai money' is not done is because of a factor in determining the amount of panai money '. The amount of the panai 'money can be determined from the prevalence or prior agreement between family members who will carry out the marriage. But unfortunately now the determination of the panai 'money cannot be seen from the sincerity and ability of the men. Many determine the amount of panai money 'from the strata level, education, descent, even seen from the beauty or good looks of both parties.

The many assumptions about the tradition of panai money make the BugisMakassar tribe people have to work hard, and struggle, in order to fulfill the requirements of the panai money 'to marry the idol of his heart, or to prepare for his marriage. One of the strong reasons that pushed them to work hard was to fulfill the main requirements of marriage according to Bugis custom, in order to be able to propose to the Bugis woman who was his lover. ${ }^{25} \mathrm{But}$ the fact is working hard is not enough to be a guarantee, so that the main conditions in Bugis traditional marriages are met. There have been many men who have had to give up their relationship and go away from their lovers

23 Interview with Mr. Agus and Mrs. Siti Hajar, an ethnic Bugis husband and wife overseas on December 18, 2018 at the house of Mr. Agus and Mrs. Siti Hajar.

24 Rosdalina, supra note 6 at 73.

25 Interview with Mr. Agus and Mrs. Siti Hajar, an ethnic Bugis husband and wife overseas on December 18, 2018 at the house of Mr. Agus and Mrs. Siti Hajar. 
to find another woman who does not ask for too much money. ${ }^{26}$ Those who do this are usually men who will marry women from among those who uphold the values of siri'.

People who uphold siri 'or shame are usually concerned with status and behavior that reflect their social strata. As proof, if the panai money 'given by ordinary men is very low to marry Bugis women from the aristocracy, then the money given is not commensurate with the social strata of his family, it will cause shame for the family of the female party $\left(\right.$ siri'). ${ }^{27}$ So that in determining the amount of panai money 'social strata is one of the most important factors.

Someone who has high social strata will be very concerned about people's views about the culture of siri'. If this happens, then the man who wants to get married, will look for a partner who has a social strata that are commensurate, according to the panai which is agreed by the man. According to the local people, the determinant of giving panai money ' is based on social status, education, ancestry, etc. which are traditions or customs of the Bugis custom. ${ }^{28}$ But, usually, the provisions of the amount of panai money apply to noble families, but no doubt the middle class community also think of the amount of panai money 'based on these factors.

Among the nobles, regard panai money 'as a culture of ancestral heritage that is no longer used as a culture that must be preserved, but a culture of prestige to boast the identity of each family, used as a venue to show the wealth of each family. ${ }^{29}$ For those marriages must keep and maintain, so that blue blood continues to flow from their circles. The big or small plan of the wedding party that is held and the prices that apply in the market are also one of the determinants of the amount of panai 'money. So if the woman

26 Interview with $\mathrm{Hj}$. Rika, the wife of $\mathrm{H}$. Arifin, a native and married Bugis couple on December 30, 2018 at $\mathrm{Hj}$. Rika.

27 Interview with Mr. Agus and Mrs. Siti Hajar, an ethnic Bugis husband and wife overseas on December 18, 2018 at the house of Mr. Agus and Mrs. Siti Hajar.

28 Interview with Mr. Agus and Mrs. Siti Hajar, an ethnic Bugis husband and wife overseas on December 18, 2018 at the house of Mr. Agus and Mrs. Siti Hajar.

Ibid. 
wants to have a large wedding party and wants to ask for a high-value delivery item, the panai money requested will be high, and this makes the man must meet the relatively high requirements. But, even though it is compulsory that the panai money 'is only used as money to buy the needs of the wedding party, so if the panai money given by the men will not influence who will be the heir, because the kinship system used by the Bugis is parental so boys and girls are considered the same, so it doesn't have to be that one of their children follows his father's line because his father paid the panai money, because the panai money is only used as money for shopping purposes not to determine who has the right to be an heir or from whom their children get their inheritance rights.

If the habit is not carried out or not followed, then there will be problems for the two families, one of which is to cause moral burdens for the family, or commonly called siri' (shame). Families will get ridicule from the surrounding community. ${ }^{30}$ Many of them also had to cancel their marriages because of the high sum of money, which caused one of the parties to decide to commit suicide or end his life. The culture of siri ' also reinforces the existence of these deeds, because their self-esteem is shamed; they are willing to exchange their lives, rather than having to live but feel burdened by the hurtful talk of people.

For the Bugis community there is also a tradition of 'panai money' required, because the money is in exchange for the love of parents who have educated and raised their daughters. ${ }^{31}$ In addition, because Bugis traditional marriages are identical to the arranged marriages by both families, they oblige the tradition by increasing the amount of panai money 'to see the sincerity of the men. The panai money tradition is also seen as bothersome and burdensome for both men and women, which sometimes creates new problems for the

30 Rosdalina, supra note 6 at 64.

31 Interview with Mrs. Fatimah and Mr. Syamsul Laksana as husband and wife of different ethnic groups on December 30, 2018 at the house of Mr. Syamsul Laksana. 
family relationship of both parties, namely, their children who decide to elope due to a canceled or delayed marriage. ${ }^{32}$

Besides that, another problem that arises from the 'panai money' is that if a man feels burdened after giving the panai money, then when there is a family dispute that causes the man to decide to divorce, many of the families of the men ask for compensation loss to court in the form of full refunds of cash. But because the panai money was classified as traditional and obligatory customary money which had been forfeited because it had been used for the purpose of a grand party with food that had been served at the wedding, the court could not grant the request of the men. ${ }^{33}$ So, the panai 'money that has been given cannot be asked to return whatever the reason, because previously there was an agreement at the time of application that men were able to fulfill these requirements.

Another impact, according to an explanation from the Bugis community, is that sometimes they feel that the panai money is troublesome for both parties, that is, the woman is also troubling the men, which in turn will affect their lives. ${ }^{34}$ First if the Bugis man and woman who has long been in a relationship then the man decides to apply, but due to the high demand for the panai, the application must be postponed until the man can fulfill the demand for the woman. With the delay in the application, men sometimes have to be in debt so that the application can proceed. In addition, a man is free if he cannot marry a previous candidate, he will look for another woman, who will later accept his application. But even though they are free to look for other women, they will also bear the shame of his actions, because he does not have a strong desire to get married, and there is no preparation before marriage. They also must be willing if the dream of marriage with their idol must be canceled or postponed until men can fulfill these

32 Interview with $\mathrm{Hj}$. Rika, the wife of $\mathrm{H}$. Arifin, a native and married Bugis couple on December 30, 2018 at Hj. Rika.

33 Interviews with Mr. H. Muhammad Tahir and Hj.Samsu Nujung husband and wife of a native Bugis tribe overseas on 3 December 2018

34 Interview with $\mathrm{Hj}$. Rika, the wife of $\mathrm{H}$. Arifin, a native and married Bugis couple on December 30, 2018 at $\mathrm{Hj}$. Rika. 
requirements. For women, the impact is that they must be willing to be single for a long period of time or become an old maid, because they have to wait for a man's proposal, because they refuse a proposal from a man because the money given is not in accordance with their wishes. It is their fault that causes the men to not be able to fulfill, that is, they always raise the amount of panai money, and in the end the woman refuses, and the proposal is canceled. That sort of thing sometimes causes many men to withdraw to marry Bugis women, and women who are ready on their own if men decide not to continue marriage.

\section{CONCLUSION}

The panai money is a tradition that starts from its grandmother is determined by several factors including, education, social strata, social status, heredity. The high requirement for panai money is actually to show the meaning of the tradition of the panai money, which is to provide lessons for men to respect Bugis women, to see the seriousness of men if they want to propose Bugis women, and to be used as a means of helping to alleviate marriage costs.

There is a philosophy that is still held by the Bugis community, that is, the kitchen with wekka pitu about marriage, the Bugis youth must work hard to get the money for marriage costs and meet the panai money which is mandatory and fairly high customary money. Due to the high amount of panai money, many Bugis migrants now no longer use panai money as the main requirement in marriage, due to the weakness of their customary values, as well as the many foreign cultures that influence it, but there are still people who continue to retain these traditions as the main conditions in marriage because of their strong customary values which they still hold even in overseas areas.

Panai money is a tradition that has long been a benchmark for the Bugis community in preparing for a wedding. Therefore, behavior that is 
repeatedly carried out and occurs, if not done it will result in moral sanctions. Moral sanctions in the form of ridicule from family and even neighbors. In addition, the change in the purpose and objectives of the panai money made the marriage null and void because the men refused the high pay. Many of his marriages had to be postponed because of the high sum of the money. The panai itself is determined by education, social strata, descent, and usually these provisions apply to high society or nobility. With this provision, some of them chose to exchange their lives if they could not meet the money, or even some of them decided to elope because the marriage had to be postponed.

\section{REFERENCES}

Ashshofa, Burhan. 1998. Legal Writing Methods. Jakarta: Rineka Cipta.

Hilman, Hadikusuma. 2007. Indonesian Marriage Law. According to the Law, Customary Law, Customary Law. Bandung: Mandar Maju.

Lamallongeng. 2007. The Dynamics of Indigenous Marriage in the Bugis Bone Society. Bone: Culture \& Tourism Office of BoneRegency.

Rato, Dominikus 2011. Marriage Law and Customary Inheritance (Kinship System, Form of Marriage and Customary Inheritance Patterns in Indonesia). Surabaya: Laksbang Yustitia.

Rosdalina., 2016. Bugis Community Marriage Implementation of Law Number 1 of 1974 concerning Marriage. Yogyakarta: Istana Publishing.

Soerjono Soekanto. 1986. Introduction to Legal Research. Jakarta: University of Indonesia (UI PRESS).

Soerjono Soekanto. 2006. Normative Legal Research A Short Review. Jakarta: Raja Grafindo Persada.

Soerojo Wignjodipoero. 1995. Introduction and Principles of Customary Law. Jakarta: Gunung Agung. 
Agustar, 2018, "The Tradition of Panaik Money in the Marriage of the Bugis Tribe in the Community of Sanglar Village, Reteh District, Indragiri Hilir Regency". JOM FISIP. Volume. 5 Number. 1.

Hajra Yansa, et, al., 2016, Panai Money and Women's Social Status in the Siri 'Cultural Perspective of the Bugis Marriage of Makassar, South Sulawesi. Pena Journal. Volume 3. Number 2.

Muh. Rusli. 2012. Reinterpretation of Traditional Marriage of the Bugis Sidrap Tribe of South Sulawesi. KARSA, Vol. 20 No. 2, December 2012.

Sri Rahayu Yudi. 2015. "Nai's Money: Between Love and Prestige". Journal of Jamal Multiparadigm Accounting. Volume. 6 Number.2.

Yunus, 2018. Islamic Values in the Marriage Process of the Bugis Society. Journal of Humanities: Islam and Culture. Volume 2, No. 1, June 2018.

Makassar Terkini. The Meaning of Daeng Calls for Bugis Tribes. In https://makassar.terkini.id/makna-p-calls-daeng-bagi-suku-bugis/. Accessed on 10 January 2019, 13.22.

\section{Interviews}

Interviews with Mr. H. Muhammad Tahir and Hj.Samsu Nujung husband and wife of a native Bugis tribe overseas on 3 December 2018

Interview with $\mathrm{H}$. Bustamin husband of a husband and wife of a native Bugis tribe overseas on 18 December 2018 at the home of H. Bustamin

Interview with Mr. Agus and Mrs. Siti Hajar, an ethnic Bugis husband and wife overseas on December 18, 2018 at the house of Mr. Agus and Mrs. Siti Hajar

Interview with $\mathrm{Hj}$. Rika, the wife of $\mathrm{H}$. Arifin, a native and married Bugis couple on December 30, 2018 at Hj. Rika.

Interview with Mrs. Fatimah and Mr. Syamsul Laksana as husband and wife of different ethnic groups on December 30, 2018 at the house of Mr. Syamsul Laksana. 